Original Research Paper

\title{
Usability of Electrical E-Wiring Module Using Mobile Apps
}

\author{
Abu Bakar Ibrahim ${ }^{1}$, Shamsul Arrieya Ariffin ${ }^{1}$, Ashardi Abas ${ }^{1}$, Mohamad Fahim Misbah ${ }^{1}$ \\ ${ }^{1}$ Universiti Pendidikan Sultan Idris, Malaysia.
}

\section{Article History \\ Received: \\ 10.09 .2020}

Revised:

20.09.2020

Accepted:

27.09.2020

*Corresponding Author: Abu Bakar Ibrahim

Email:

abubakar.ibrahim@fskik.upsi. edu.my

This is an open access article, licensed under: $\mathrm{CC}-\mathrm{BY}-\mathrm{SA}$

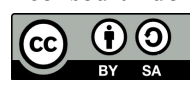

Abstract: In education, the use of smart-phone apps is very helpful in the process of teaching and learning. Therefore, this situation inspires and opportunities for the development of a smart-phone app namely the Electrical e-Wiring Module (called, MePE). The MePE app is a smart-phone app or mobile apps developed to help students who are taking electrical wiring courses to refer how to learn electrical wiring via smart-phone applications. In addition, this application can also be used as a teaching tool in the process of learning electrical wiring. The study was conducted to identify the requirements for MePE app, develops and tests the functionality of MePE app. There are four main sections in this application. This application is developed in accordance with the evolutionary prototype methodology. As a result of the functionality testing performed on the nine functions available on the MePE app all the functions passed the tests that have been performed. In addition, 24 of 31 respondents agreed that the MePE application is helpful and effective in learning electrical wiring. It is hoped that with this application it will help students that study electrical wiring courses to make reference to electrical wiring through this application.

Keyword: Electrical Wiring, MePE, Mobile Apps. 


\section{Introduction}

Information and Communication Technology (ICT) technology covers all technologies that help disseminate information such as radio, television, mobile phones, computers and the internet. This has affected the education and its impact can be divided into three phases namely the replacement phase, transition phase and phase of change [1]. In the replacement phase, teachers make them as a tool for teaching and learning sessions without changing teaching methods, while in the transition phase, teachers use ICT that can stimulate changes to new teaching methods. For the phase of change, it involves a fundamental change in the role of students and teachers in teaching and learning. The rapid development of information and communication technology affects almost all aspects of life including education. Developments in technology have also changed the way people learn [2]. In addition, the learning process has now surpassed the physical space of the classroom [3], being globalized and lifelong [4]. As such, the education system in Malaysia is also influenced by this, especially in relation to ICT applications in teaching and learning.The world is in the digital era where the source of knowledge is the pulse and backbone of the success of a nation especially in education.

Technologists in the field of education are indispensable especially the use of smart-phone apps in helping teachers deliver lessons learned. Smart-phone apps are apps built into smart-phones, tablets and mobile devices. Most smart-phone operating system developers have provided a platform that allows users to download applications. Among the app distribution platforms that record the highest number of app downloads are Apple Store, Google Play, Blackberry App World and Windows Phone Store [5]. In the field of education the use of smart-phone apps is especially helpful in learning and teaching. Therefore, this situation inspires and opportunities for the development of a smart-phone app namely the Electrical e-Wiring Module (MePE). MePE developed aims to help students who take electrical wiring courses to make references about electrical wiring through smart-phone applications.

\section{Literature Review}

Education has an important role in developing a country to ensure the sustainability of a society. Through education, quality energy sources can be produced. By the way, education and technology are mutually dependent and inseparable. The use of media and technology is an interactive learning. Students do not just use paper and stationery to present their understanding of modules or subjects learned even more when technology is applied in education. According to Nor Azlina [6], traditional or conventional teaching methods that practice in teaching and learning today will not be able to meet the demands of the 21 st century education. Learning is no longer focused on the classroom alone, but teaching methods are also evolving as technology develops in Malaysia. For example, traditional textbooks can not cope with the ups and downs of information that are in line with the era of circulation [7].

The use of technology in the field of education should not be subject to limitations or constraints that may impede the teaching and learning process. Therefore, constraints in the information and communications technology infrastructure at schools or institutions of higher learning should be addressed immediately [8]. Quality education can produce good student output or output. The lack of infrastructure in education and other factors such as background and socioeconomic of student families, individual student developments, and other physical and social environments may be an obstacle for an individual to succeed in education and his life [9]. Starting with learning and learning methods using blackboard and chalk turned to the use of technology namely computers, electronic materials, Liquid Crystal Display (LCD), video cameras and the latest smart-phone applications used in the study rooms. From time to time, education through changes is in line with the advancement of thought, will and teaching technology. In line with the technological developments in education, the Electrical e-Wiring Module (MePE) has the potential to assist students who are following the electrical wiring courses to understand and know more about electrical wiring.

Lack of reference material for learning is one of the causes for a student's misunderstanding of what is learned. This is because the reference material can be used as a guide by students in understanding the lessons learned. In the absence of a reference material, students are less likely to understand what they are learning. Utusan Malaysia reports that reference material is important as it is an added value to the learning notes given by teachers [10]. In fact, this reference material has the latest information that can help students when reviewing the lessons. Indeed, students are encouraged to make a reference so that all new information is obtained immediately. Therefore, the use of technology in the field of education provides an opportunity for the development of smart-phone applications in order to make the application a reference material such as textbooks. This allows 
students to access the references more easily. Additionally, making this smart-phone application as a reference material such as textbooks gives students the ability to access the references anywhere. This can help students with learning goals and can make it easier for students to access references [11]. Electrical wiring courses are not an easy course for a student to learn. This course requires a student to understand exactly the exact way, the tools used and the safety for electrical wiring. Lack of reference materials on electrical wiring, especially the reference materials in the form of smart phone applications, greatly exchanges students to understand accurately the electrical wiring. Hence, with the availability of reference materials on electric wiring in the form of smart tele applications can provide students with ease in learning electrical wiring accurately and easily [12].

\section{Methodology}

There are various development methodologies that can be used as guides throughout the development process of a system or application where the suitability depends on the project to be developed.

\subsection{Evolutionary Prototype Model}

The methodology to be used throughout the application development process is the evolutionary prototype methodology. This methodology will use the concept of prototype and each of the functions and content contained in the application will be added one by one according to the requirements of the user. This evolutionary prototype model is best suited for the development of projects with multiple interactions with target users. Additionally, target user engagement in the development of this application will help identify the requirements that need to be present in this application. In addition, the use of this methodology also allows developers to modify or adding the requirements that need to be in the application according to the usage requirements during the development of this application [12].

Figure 1 shows the Evolutionary Prototype development model.

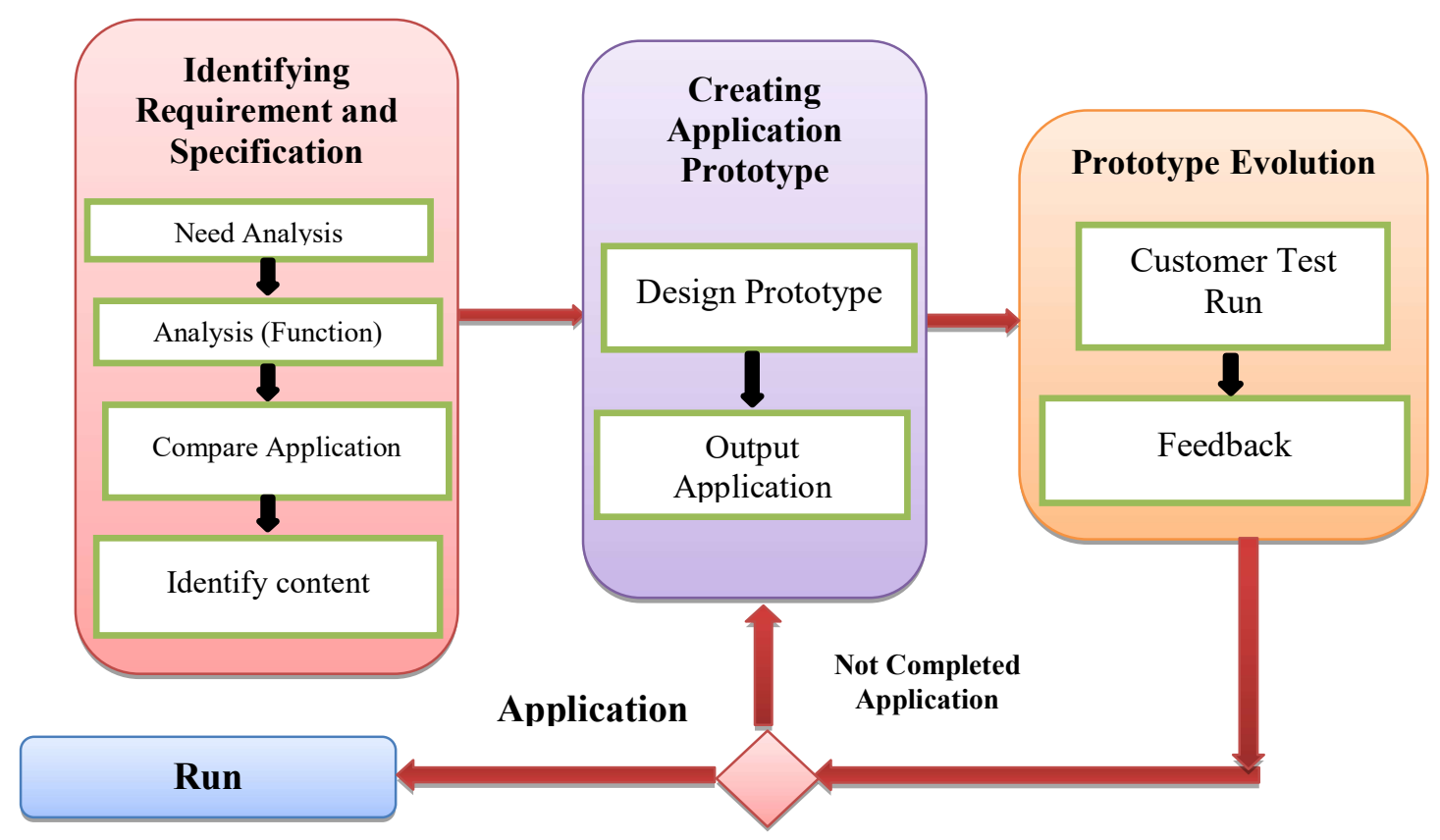

Figure 1. Evolutionary Prototype Development Model

Application prototype will be developed through initial analysis. Then the application prototype that has been developed will be provided to users for testing. Then the user will give comments and feedback regarding the application prototype. If there is a shortage in the application, the developer will update the app. This process will repeat until the application is complete and meets the needs of 
the user and the user is satisfied with the application that has been developed. Using this model, any errors or shortcomings can be detected at an early stage to avoid the risk of the project being produced not meeting the requirements of the user after the application is completed. Evolutionary Prototype model is a system or application development methodology that can be used to show users systems or applications first. This methodology is the development of a life-cycle software model in which it was created for demonstrations and it is a system or application development methodology that is incomplete developed early on system or application development [13]. The objective of this methodology is to produce a fully functioning application to the user. Starting with the needs of users to be examined clearly, the prototype is built and assessed by the user so the specifications are met before being implemented as a complete end-application.

\subsection{Methodology Phases}

This part describe about the phases in the research.

\section{Phase: Identifying Requirements and Specifications}

In this phase, developers will perform preliminary analysis of the required requirements in the application that will be developed later. The methods used to obtain information are through articles, research materials, websites and existing app analysis. Based on the information obtained, to produce an application that can help in the learning of electrical wiring is that the application should have enough material related to the electrical wiring. For example, in one app it must have complete notes about electrical wiring, video on how to conduct electrical wiring, information on safety for electrical wiring and electrical-related calculations. Based on the existing analysis of existing applications, most existing applications do not have sufficient aspects or content in the application. Therefore, developers need to provide all of the above mentioned aspects to make the applications to be developed to assist in learning electrical wiring.

\section{Phase: Creating Application Prototype Phase}

In this phase, the prototype is designed and produced. A first prototype that contains requirements that have been analyzed in the previous phase. However, in this phase the built-in prototype does not really emphasize on the quality of graphs but only tests whether the functions and content in the application coincide with the needs of the users.

\section{Phase: Prototype Evaluation Phase}

This phase is where prototypes have been constructed to the user for testing. The user will provide comments and feedback on the functions and contents contained in the prototype. As a result of the user's comments and feedback, developers will use the information to identify whether the fungi and content contained within the application are complete or require any additions. If there is any addition, the builder will repeat the phase of generating the application prototype. However, the prototype of the previously generated application does not exist but only new functionality or content will be added to it.

\section{Phase: Application Launch Phase}

In this phase, after users are satisfied with all the fungi and content in the application and the application is considered complete, it is ready to be launched to target users.

\section{Finding and Discussion}

In the development of a simple design application is very important but it is able to attract users, especially students who are following the electrical wiring course which is the main target group of applications. Before the application generation took place, the basic structure of the app content was first translated into a simpler and easier-to-understand form of the user [14] [15]. In addition, the activity flow diagram and application sequence are generated to make it easier for users to know the movement of the MePE app.

\subsection{Design Application of Electronic Wiring Module}

Design modeling is designed using certain methods or models to facilitate users to understand processes, functions and activities that occur in a system or application. There are five processes that 
occur when the design modeling is done: input, output, user interface, system function and control and maintenance.

\subsection{Application Architecture Electrical e-Wiring Module}

Figure 2 shows the architecture is a model that explains the structure of the application as well as an overview of the application. This application uses a car app architecture that uses PhoneGap architecture because this application is built using Adobe PhoneGap. There are some important parts in this architecture to form the MePE application. Among the sections are Web App, PhoneGap Plugins and Mobile Operating. On Web App part HTML code, JavaScript, CSS and config.xml are generated and web-generated display before being converted to an app that has the .apk format using Adobe PhoneGap by uploading those codes in Adobe PhoneGap. PhoneGap Plugins is intended to enable a working media on smart-phones and Mobile Operating to ensure the Android platform functions on smart-phones.

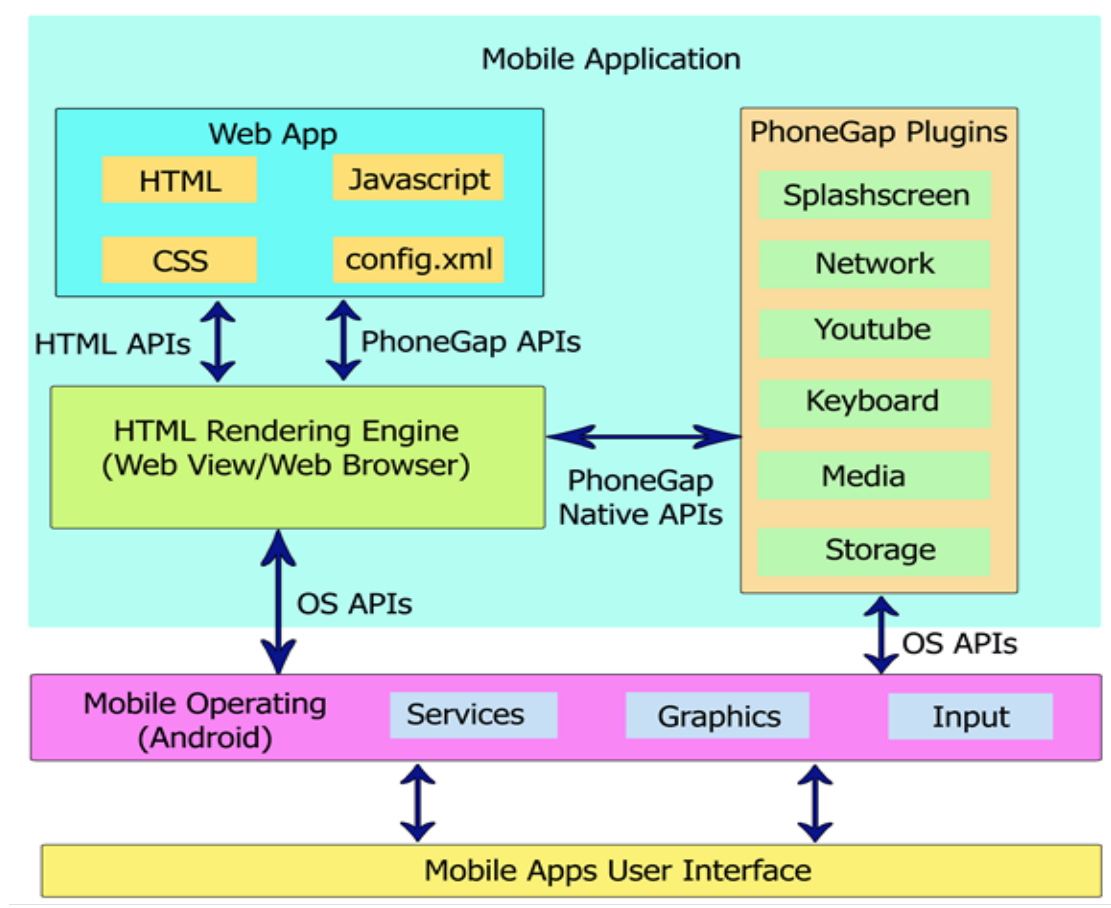

Figure 2. The MePE Application Architecture

The questionnaire which has been done on the respondents has been evaluated for research data. The data from the questionnaires were analyzed to obtain the perception or respondents' perception on MePE application. The graph was used to show the result of the questionnaire. From the result of this questionnaire, the researcher can see the usability of MePE application on the learning of electrical wiring.

Usability testing is aimed at obtaining user views on app design and application. Tested applications are still in the phase of improvement which is also known as prototype. Responder was asked to use the MePE app and provided feedback after using this application by filling out a questionnaire.

Table 1 shows the percentage of usability of MePE applications by category, while Figure 3 shows the usability graph of MePE application by category. Based on the figure, the respondents' view of MePE application usability is as follows for the 6 per cent application interface stated less usable, 71 per cent can be used and 22 per cent is very usable. Additionally, for text on the application, 22 per cent said it can be used, 71 per cent said it could be used and 6 per cent said it was less usable. Additionally, for images and graphics available on the app, 6 per cent stated that it is less usable, 74 per cent can be used and 19 per cent said it is very usable. 
Table 1. The Percentage of Usability of MePE Applications by Category

\begin{tabular}{lccc} 
& \multicolumn{3}{c}{ Percentage $\%$} \\
Categorize & Less Usable & Usable & Very Usable \\
Interface & 6 & 71 & 22 \\
Teks & 6 & 71 & 22 \\
Imej/Grafik & 6 & 74 & 19
\end{tabular}

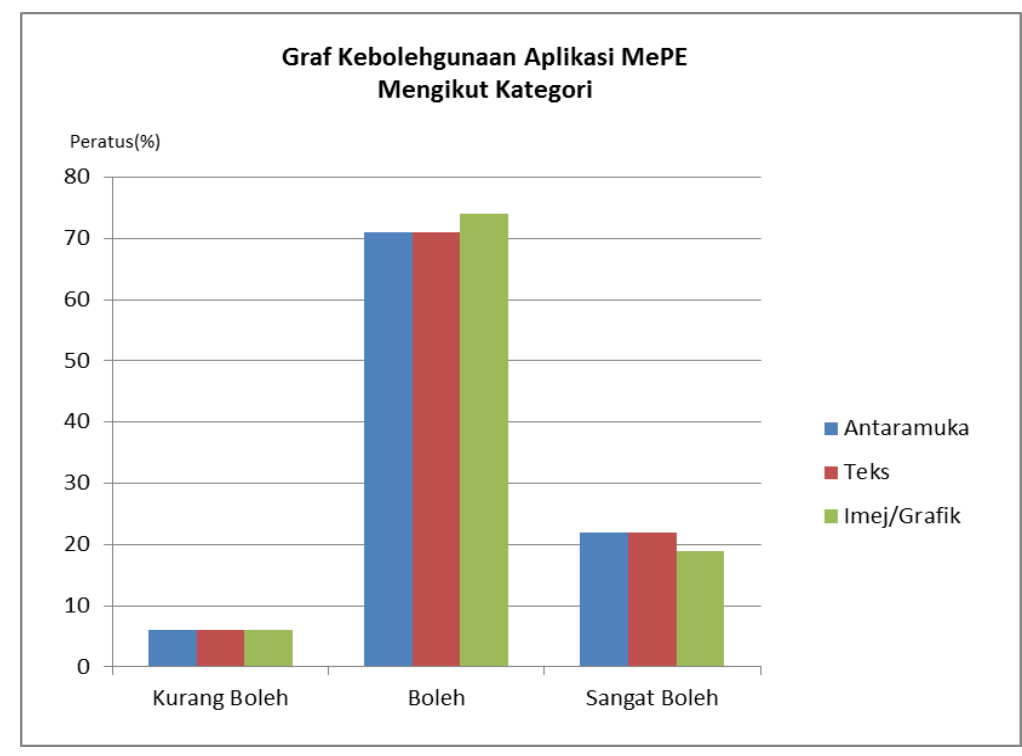

Figure 3. The Usability Graph of MePE Application

\section{Conclusion}

Overall, this application has been successfully developed in accordance with the plans that have been made and meet the requirements of the development as outlined. However, there are still plenty of room for improvements that can be made and the development of ideas that can be made to further improve the quality of this apps. It is hoped that with this application, a little bit will help students who are taking electrical wiring courses to make reference to electrical wiring through smart-phone applications, allowing them to learn electrical wiring easily and effectively.

\section{References}

[1] N. A. Rahim, Penggunaan Mobile Learning (M-Learning) Untuk Tujuan Pembelajaran Dalam Kalangan Pelajar Kejuruteraan. Malaysia: UTHM, 2013.

[2] S. Azmi, Pembangunan Aplikasi Panduan Solat Untuk Platform Android (Muslim Solah). Johor: Universiti Teknologi Malaysia, 2013.

[3] J. Muthusamy, "Keberkesanan Kaedah Demonstrasi Video dalam Pengajaran dan Pembelajaran bagi Modul Pendawaian Elektrik Tiga Fasa," Journal of ICT in Education, vol. 6, 2016.

[4] N. F. F. Zarwawi, Pelaksanaan Pembelajaran Melalui Buku Teks Digital Dalam Memperkasakan Pengajaran Guru di Sekolah. Johor: Universiti Tun Hussein Onn Malaysia, 2015.

[5] A. Nawi and M. I. Hamzah, "Tahap Penggunaan Telefon Bimbit Sebagai M-Pembelajaran Dalam Pendidikan Islam," Journal of Islamic and Arabic Education, vol. 5, no. 1, pp. 1-10, 2013. 
[6] N. Azlina, Aplikasi M-Learning Dalam Pendidikan Koperasi. Kuala Lumpur: Maktab Koperasi Malaysia, 2013.

[7] A. S. Hanif, M. N. Azman, H. Pratama, and N. N. M. I. Ma'arof, Kit pemantauan penyambungan litar elektrik: Satu kajian efikasi Alat Bantu Mengajar, 2017.

[8] B. Ismail, J. Ayob, M. Alias, and N. Kaprawi, Penjuruteraan Semula Pendidikan Teknikal dan Vokasional: Satu Cetusan Pemikiran dan Tinjauan, 2004.

[9] -, "Kajian Menunjukkan Pelajar Tidak Mampu Guna Telefon Dan Belajar Secara Serentak," June 14, 2015. [Online]. Available: http://www.astroawani.com/berita-malaysia/kajian-me nunjukkan-pelajar-tidak-mampu-guna-telefon-dan-belajar-secara-serentak-62357. [Accessed: June 2020].

[10] -, "Peranan Bahan Rujukan," August 5, 2005. [Online]. Available: http://ww1.utusan.com.my/ utusan /info.asp? $=2005 \& \mathrm{dt}=0805 \&$ pub=Utusan_Malaysia\&sec=Pendidikan\&pg=pe_09.htm. [Accessed: June 2020].

[11] C. Anwar, and J. Riyanto, "Perancangan Sistem Informasi Human Resources Development pada PT. Semacom Integrated", ijeste, vol. 2, no. 1, pp. 19 - 38, Jun. 2019.

[12] A. Hamdan, and S. Z. A. M. Rosseni Din, "Penerimaan M-Pembelajaran Dalam Sistem Pendidikan Di Malaysia Melalui the Unified Theory of Acceptance and Use of Technology (UTAUT): Satu Analisis Literatur," in 1st International Conference on Mobil Learning, Applications, and Services, 2013.

[13] R. Wijayanti, and S. Mulyati, "Rancangan Bangun Sistem Informasi Pemantauan Produksi dan Kegiatan antar Divisi", ijeste, vol. 1, no. 1, pp. 1-14, May 2019.

[14] O. N. Fadzilah, Kajian Tahap Penggunaan Aplikasi Web 2.0 Dalam Kalangan Pelajar Institut Pengajian Tinggi Awam di Malaysia. Johor: Universiti Teknologi Malaysia, 2010.

[15] F. Duwiyanti and M. Ardhiansyah, "Sistem Pendukung Keputusan Pemilihan Guru Terbaik di SMK Pustek Serpong", International Journal of Education, Science, Technology, and Engineering, vol. 2, no. 1, pp. 45-67, Jun. 2019. 